\title{
GENDER EQUALITY IN ISLAMIC RELIGIOUS EDUCATION
}

\author{
Abdul Karim \\ State Islamic Institute of Kudus \\ Email: akarim_4alp@yahoo.com \\ Pryla Rochmahwati \\ State Islamic Institute of Ponorogo \\ Email: pryla@iainponorogo.ac.id
}

\begin{abstract}
This research is remarkable to conduct research dealing with its impact on the senior high school students' achievement. The design of the research was a phenomenological qualitative approach. It was applied by using purposive sampling in Kudus Regency. The findings showed that (1) Islamic Religious Education placed men and women equally in the teaching and learning process. However, the difference in learning material is based on the essence of the source of Islamic law of Al-Quran and Hadith; (2) There are several learning models applied, directed free learning strategies which stimulate students for behaving and acting according to normativerational and religious considerations and resulting in learning changes in thinking, behaving and acting according to individual ratio considerations; (3) The impact of the Islamic Religious Education learning model on understanding gender equality is that the presence of a normative-religious, normative-rational understanding, as well as a rational understanding of gender issues.
\end{abstract}

Abstrak: Penelitian ini bertujuan untuk mengetahui pengaruh kesetaraan gender terhadap prestasi belajar peserta didik di Sekolah Menengah Atas (SMA). Penelitian ini mengambil lokasi di Kabupaten Kudus (berdasarkan purposive sampling) dengan menggunakan pendekatan kualitatif fenomenologis. Dari hasil analisis data penelitian ditemukan, pertama: Pembelajaran PAI dilaksanakan dengan tanpa membedakan gender peserta didik. Perbedaan materi pembelajaran didasarkan pada esensi sumber hukum Islam al-Quran dan Hadits. Kedua, terdapat beberapa model pembelajaran yang diterapkan, yaitu dengan menggunakan strategi pembelajaran bebas terarah yang merangsang siswa untuk berperilaku dan bertindak sesuai pertimbangan normatifrasional dan religius sehingga mengakibatkan perubahan sikap peserta didik dalam berpikir, berperilaku dan bertindak sesuai dengan pertimbangan rasio individu. Ketiga, ada beberapa dampak model pembelajaran PAI terhadap pemahaman kesetaraan 


\section{Abdul Karim dkk, Gender Equality}

gender, di antaranya: model pertama, peserta didik memiliki pemahaman secara normatif-religius; model kedua, peserta didik memiliki pemahaman tentang gender secara normatif-rasional; dan model pembelajaran ketiga, peserta didik memiliki pemahaman permasalahan gender secara rasional.

Keywords: Islamic religious education; gender equality

\section{INTRODUCTION}

The term 'gender' has been incorrectly used to refer to 'sex.' Sex is associated with males and females, determined purely by genetics. ${ }^{1}$ As a result, they are not always similar. In addition to gender distinctions, some researchers believe that three factors can differentiate males from females: chromosomes, the brain, and behavior.

The government's commitment to realizing gender equality and justice has been clearly stated in the constitution in the form of laws and regulations, namely the Regulation of the Minister of National Education Number 84 of 2008 concerning implementing gender equality in the education sector. This regulation emphasizes gender equality in education which is manifested in (1) improving access of all citizens to education services in all types of education; (2) increasing women's participation in every policy-making, its planning as well as its implementation at all levels of the education bureaucracy; (3) increasing men's and women's capabilities in managing the sources of information and knowledge; and (4) providing the similar opportunity for men and women to obtain benefits from all education programs. ${ }^{2}$

Nowadays, injustices caused by inequality of gender still occur. There are many factors for gender discrimination, including gender bias in interpreting religious texts and patriarchal culture. ${ }^{3}$ The interpretation of religious texts obeys the context when a verse revealing the Quran will create a bias meaning. Therefore, it leads to the orientation of one-sided understanding and intention for both men and women.

The patriarchal cultural system has placed the superiority of men over women; men are positioned higher in rank than women. ${ }^{4}$ In social affairs that

1 Nurachman Hanafi et al., 'Students' Ability in Varying English Sentences: A Gender Approach', Cendekia: Jurnal Kependidikan Dan Kemasyarakatan 17, no. 1 (2019): 1-16.

2 Kementerian Pendidikan Dan Kebudayaan, 'Peraturan Menteri Pendidikan Dan Kebudayaan Republik Indonesia Nomor 84 Tahun 2014' (Jakarta: KEMENDIKBUD, 2015).

3 Triana Sofiani, 'Tafsir Agama Dan Kekerasan Berbasis Gender', Jurnal Penelitian 5, no. 2 (2013).

4 Reiko Ozaki and Melanie D Otis, 'Gender Equality, Patriarchal Cultural Norms, and Perpetration of Intimate Partner Violence: Comparison of Male University Students in Asian and European Cultural Contexts', Violence against Women 23, no. 9 (2017): 1076-99. 
require interaction with many people must be handled by men. Meanwhile, activities in the house and its surroundings are positioned as the responsibility of women, even though the type and volume of work require a large amount of labor. The results are better than those done by men. ${ }^{5}$

This understanding results in the role of women who are considered complementary, activities carried out to complement men's duties to divide the scope of life into the domestic and public domain. Women are placed in the space of domestic life, while men are in public life. It is essentially a genderbiased attitude from the adaptation of local culture. ${ }^{6}$ The behavior that is created by the community does not mean that it originates from religious values. Still, it grows and develops based on the community's agreement, which is considered to have basic norms as if it is a binding religious doctrine. Nevertheless, some words, sentences, or behavioral attitudes come from institutionalized habits resembling religious teachings.

In the Islamic perspective on gender equality, the Quran emphasizes that men and women are both (1) servants, (2) caliphs, (3) accept the primordial agreement, (4) actively involved in cosmic dramas (Adam and Eve), and (5) have the potential to gain achievement. ${ }^{7}$ It can be further understood that humans are servants. There is no difference between men and women because each one will get an award from God according to the level of their devotion (Surah Al-Nahl: 97). Both have the same potential and opportunities to become ideal servants (Surah al-Hujurât: 19). However, men are placed higher than men in some cases, such as husbands and wives. Men protect women, get more inheritance, and do polygamy. It leads to the wrong assumption that men become prominent servants. These advantages are given to men in their capacity as members of society who have more public and social roles at the time the verses of the Qur'an were revealed.

Gender inequality has been increasingly rooted in social life when genderbiased values are carried out through the learning process in schools. However, the educational administration has not integrated gender equality values in the learning process for several reasons. First, the teachers' limited understanding of the concept of gender equality related to Islamic Education, resulting in gender-nuanced material between men and women, has not been appropriately formulated. Second, there is no clarity on the curriculum as a reference for

5 Agus Purnomo, 'Teori Peran Laki-Laki Dan Perempuan', Egalita 1, no. 2 (2006).

6 Rakhmat Hidayat, 'Bias Gender Dalam Prestasi Akademik Siswa: Studi Tentang Perbandingan Prestasi Akademik Siswa Laki-Laki Dan Perempuan Di SMA 12 Bekasi', Jurnal Pendidikan Dan Kebudayaan 17, no. 4 (2011): 472-79.

7 Muhammad Rusydi, 'Esoterisme Pemikiran Gender Nasaruddin Umar', AN-NISA: Jurnal Studi Gender Dan Anak 12, no. 2 (2020): 710-16. 
learning that shows a proportional separation of gender equality. Third, there are methodological limitations for developing Islamic education based on gender equality.

The result of preliminary observation revealed that Islamic Religious Education in senior high school had not paid equal attention to gender issues. PAI learning has a strategic position to instill the values of gender equality for students. However, its implementation tends to be gender-biased. Furthermore, the number of female students outweighs the number of males. This condition requires fair and correct service to fulfill the needs of learning and other daily necessities. One of the predisposed vital facilities is the provision of toilets. The number and design of the buildings are equalized between men and women.

Learning strategies that integrate gender equality can impact male and female students in getting different experiences when they learn in the classroom. It can affect various aspects, such as the level of class participation as well as learning outcomes. Social and cultural values and gender stereotypes can inadvertently occur in the classroom and at school through interactions between teachers and students and among students. Disproportions of teaching approaches and methods used in teaching, assessing, and interacting with students place males' preferences over females. It is often occurring because of the habit of female students to speak in public and raise the question that is mainly under male control. $^{8}$

The issues above require attention to straighten out by taking a balanced attitude in all actions in learning. It could trigger dissatisfaction or violence, either from women's groups or vice versa, due to gender injustice. The development of unfair attitudes within the household and society is likely triggered by an unbalanced understanding of treating male and female family members.

It provides relevant information related to the teaching and learning process of Islamic Religious Education in senior high schools in Kudus. An indepth study is required to obtain an overview of Islamic Education learning from a gender perspective. This research aims to answer the following research problems. First is how the learning model of Islamic Religious Education in senior high school is viewed from gender equality. Second, implementing the learning model of Islamic Religious Education, which integrates gender equality, impacts the students' learning outcomes. The third is the impact of the learning model of Islamic Religious Education on students' understanding of gender equality in senior high schools?

The result of the research is significant since it provides high-quality input to schools and education providers to improve learning models and material. In

8 Bahrul Hayat, 'Perempuan Dan Pendidikan Dalam Perspektif HAM', Millah: Jurnal Studi Agama 11, no. 1 (2012): 193-217. 
addition, it determines policies related to the implementation of Islamic religious education and learning in schools and communities. Finally, it considers that the mistake of learning Islamic Religious Education will substantially impact the formation of religious behavior.

\section{THEORETICAL REVIEW}

\section{Learning and Gender Equality}

Learning based on gender equality is a learning process recognizing and considering equivalence between male and female students. ${ }^{9}$ Equality in the learning process shows that male and female students accept fair treatment and attention and the same opportunity to learn. Both have the same access, participation, control, and benefits in learning.

Through the learning process, students will understand the values of gender equality as well as learning experiences. This method will provide alternative experiences for students that can influence and even change the initial gender construction of children, which is immovable from the patriarchal cultural system. The change is expected to provide students' understanding of the equality rights and obligations in life between men and women and the nature and character of a person based on understanding and equality.

Education is one of the foundations for building a process of change in understanding gender. It is a form of activity that has been considered influential in providing a process of understanding knowledge. Therefore, an educational institution is a place for transferring knowledge to society. Therefore, efforts should be made to realize gender justice from the very beginning. To realize it, some necessary steps must be elaborated: first, to enforce gender justice in education and eliminate differentiation among students. Second, to seek justice among the leadership; third, to reduce the causes of violence and discrimination through the material taught and provide a learning process containing stereotyping.

Several components contribute to incorporate gender equality-based learning, encompassing teachers, textbooks, gender-based learning methods. ${ }^{10}$ The teacher becomes the initiator in the learning process by formulating and defining the lesson content for achieving students' learning outcomes. The curriculum is considered to be the main element for the implementation of gender mainstream in education. The curriculum is a means to develop the

9 Mufidah Ch and Zainal Habib, Psikologi Keluarga Islam Berwawasan Gender (Malang: UIN-Malang Press, 2008).

${ }^{10}$ Elaine Unterhalter, '2 Global Values and Gender Equality in Education', Gender Education and Equality in a Global Context, 2007, 19. 
vision and mission of an educational institution. ${ }^{11}$ Through the curriculum, gender equality blended in its vision and mission, which is then implemented through learning and other curriculum components.

\section{Islamic Religious Education and Gender Equality}

Allah revealed Islam to become a religion to be rahmatanlilalamin. Therefore, the teachings conta ined in the source of Islamic religious education always uphold values that benefit humankind. Concerning the relationship between men and women, the basic principles of Islam are equality and justice. This principle can be found in some verses of the Quran that explicitly acknowledge men and women's equal position, including QS. Al-Hujurat (13), "Human beings, We created you all from a male and a female and made you into nations and tribes so that you may know one another. Verily the noblest of you in the sight of Allah is the most God-fearing of you."

According to Nasaruddin Umar, the above verse explains that there is no difference between men and women in the human capacity as a servant. ${ }^{12}$ Both have the same potential and opportunities to become ideal servants. This verse also explained that the whole of humankind had been addressed to reform it of the great evil that has always been causing universal disruption globally: the prejudices due to race, color, language, country, and nationality.

The inequality of the roles of men and women is not recommended by religion. On the con trary, God views the same opportunities between men and women in competing for good deeds (Surah Ali Imran: 195). It shows that equality at the level of individual potential development, including educational activities, is seen. In the Qur'an, there is no statement that women are created from a material that is lower than men. Also, women are inferior since they are created from one of the left ribs of men.

Saroh Faiqoh's p revi ous research of gender bias in the Fiqh learning curriculum occurs in the syllabus, the lesson plan (RPP), material at Madrasah Aliyah Negeri Klaten. Gender bias also occurs in the provision of male and female as well as the preparation of RPP. ${ }^{13}$ It leads to women's subordination role in the learning process. Furthermore, the use of language, the delivery of illustrated images, and the content of the explanatory material resulting in attitudes of marginalization of women, subordination, and double burden. The use of the

${ }^{11}$ Muhammad Anas Maarif and Muhammad Husnur Rofiq, 'Pola Pengembangan Kurikulum Pendidikan Pesantren Berkarakter: Studi Pondok Pesantren Nurul Ummah Mojokerto', TADRIS: Jurnal Pendidikan Islam 13, no. 1 (2018): 1-16.

${ }^{12}$ Nasaruddin Umar, Argumen Kesetaraan Jender; Perspektif Al-Qur'an (Jakarta: Paramadina, 1999).

${ }^{13}$ Iin Saroh Faiqoh, 'Bias Gender Dalam Kurikulum Mata Pelajaran Fikih Di Madrasah Aliyah Negeri Klaten’ (Thesis, Yogyakarta, Program Pascasarjana UIN Sunan Kalijaga, 2009). 
language of the delivery of images and illustrations is a part of understanding the regularly occurring material. However, suppose gender-biased learning is not observed. In that case, it will have an impact on the formation of behavior based on injustice. It may lead to negative attitudes such as apathy, indifference, and a lack of a competitive life force, affecting affection learning behavior.

\section{RESEARCH METHODS}

This research employed a qualitative phenomenological approach. It aims to explore inductive facts in the field into a report to provide an overview of the model obtained for ascertaining a social reality. ${ }^{14}$ This type is considered according to the research objectives, which scrutinize a learning model of Islamic Religious Education in senior high school and its relationship with gender equality. This research also aims to find new knowledge through 'basic research' or to answer specific questions about practical issues related to gender implementation. In addition, to describe the changes that occur due to the learning model implemented by following the research model Nana Syaodih Sukmadinata, namely the preliminary study, extracting the model, and validating the verification of the model provided. ${ }^{15}$

This research was conducted in several senior high schools in Kudus Regency based on choice according to purposive sampling, namely at SMA NU al-Ma'ruf, SMAN 2 Kudus, SMA Muhammadiyah in Kudus Regency. This setting selection was based on representing educational institutions managed by the government and the private sector. As a result, many female students are considered for formulating a gender equality-based Islamic Education learning model. In addition, each male and female student has the privilege to develop the learning process proportionally.

Data collection techniques were carried out through direct and indirect observation, ${ }^{16}$ formal and informal interview documentation, and attitude scales. Then, they were analyzed by Mattew B. Milles and A. Michael Huberman views of qualitative research consisting, (1) determining the category and coding of data to facilitate interpretation and further verification of data; (2) reduce data from several data obtained from the field, by summarizing and recording key points relevant to the research focus and systematically arranging them based on specific categories and classifications; (3) display and classify data, and (4)

${ }^{14}$ Burhan Bungin, Penelitian Kualitatif: Komunikasi, Ekonomi, Kebijakan Publik, Dan Ilmu Sosial Lainnya, vol. 2 (Jakarta: Kencana, 2007).

${ }^{15}$ Nana Syaodih Sukmadinata, Metode Penelitian Pendidikan (Bandung: PT Remaja Rosdakarya, 2008).

${ }^{16}$ Lexy J. Moleong, Metodologi Penelitian Kualitatif (Bandung: PT Remaja Rosdakarya, 2002). 
conclusion drawing / verifying. ${ }^{17}$ The research also applied data triangulation techniques for confirming validity as well as the objectivity of the findings through testing credibility, dependability, confirmability, and transferability".

\section{FINDING AND DISCUSSION}

\section{Islamic Education Teachers' Perceptions of Gender Equality}

According to Agung Marzuki (Islamic Religious Education teacher), equality disagrees with the view that there is a difference in degrees between men and women. He said further that basically, women and men have the same degree. They have the same opportunity to participate in any field. There is no discrimination between men and women in the Quran.

Islam recognizes these differences between men and women, as stated by Ahmad Fuad (Islamic Religious Teacher). However, Islam does not justify discrimination between them. The differences are due to the physical-biological state of women who are destined to be different from those of men. However, this difference does not mean that Islam glorifies one of them and disparages others. Islamic teachings do not distinguish in detail the factors of differences between men and women. Still, it concerns the two as a whole.

A wife respects a husband in family life does not mean that the husband merely provides for it. Still, they should respect each other. Moreover, the phenomenon of wives who earn a living appears nowadays. Men and women have equal positions. Each has equivalent opportunities to enroll in all life aspects. Anyone who has abilities, regardless of gender, should be allowed to develop progressively.

Some verses of the Quran that briefly showed discrimination against women should not be understood partially. The Quran never differentiates between people based on a particular gender. Men are given the same opportunity to compete to increase their charity. Despite having a view that places men and women as equal, Khusnul Aqibah excludes household leadership. In household affairs, she still tends to have the husband become the head of the household. Husbands must be responsible for fostering and building a household. In this case, he adheres to Surah an-Nisa verse 34. Men are women's leaders because Allah has exaggerated others (women) and because they (men) have spent part of their wealth.

Women often get less fair treatment than men. Women are often subordinated and underappreciated. However, these unfavorable positions and treatments seem to derive legitimacy from theological or religious doctrines in the form of interpretations that are full of gender bias. Some scholars argue

${ }^{17}$ Matthew B. Miles and A. Michael Huberman, Qualitative Data Analysis: An Expanded Sourcebook (California: Sage Publications, 1994). 
that Quran gives special treatment and several privileges to men than women. Because of that, the position and role of men are more prominent than women.

Several verses of the Quran are often used as arguments to legitimize the privileges of the degree and position of men and, at the same time to give rise to discriminatory treatment of women. It includes (1) creation of women from the ribs of men, as stated in the Surah an-Nisa (1); (2) male leaders for women and men can beat to teach lessons in nusyuz (domestic violence) as stated in the letter an-Nisa (34); (3) as stated in Surat an-Nisa' (11-12; (4), the share of male inheritance is twice that of women - men have the privilege to practice polygamy, as stated in Surat an-Nisa (3).

\section{Learning Islamic Religious Education in a Gender Perspective}

Islamic Religious Education and character learning in SMA I Kudus is held two hours per week. This time allocation is inadequate to cover the essential competencies aimed at fostering students' abilities in the cognitive-affective and psychomotor domains

To achieve competency standards and basic competencies as required by the 2013 curriculum, the competencies achieved are the mastery of knowledge, skills, attitudes, and values reflected in habits of thinking and acting. This definition implies that Islamic Religious Education learning is simply by educating the students to understand the content. Still, it is also necessary to develop other students' potentials regarding skills, values, and attitudes through religious topics.

The curriculum explicitly does not provide signs that regulate Islamic Religious Education learning implementation based on thorough gender analysis. For example, in a classroom arrangement that involves seating. Students are given the freedom to choose seats based on an agreement with class friends under teacher guidance. Another seating formation is that women occupy the left side of the class and men on the right. Some women occupy the front row, and men are at the back of the class. Observation revealed that some schools put the first pattern, and some followed the second pattern. In certain schools that apply Islamic norms, they prefer that female student are at the forefront of the class and boys are at the back. The reason is more on a normative-ethical orientation, namely to conquer the possibility of causing a commotion. In this case, women get more protection and treatment based on considerations of religious values than men.

According to the Islamic Religious Education's teachers, if female students are placed side by side with men and not in the same group row (mixed with male and female), it can cause several problems. First, it can cause uncomfortable feelings for stude $\mathrm{n}$ ts. Second, it creates an opportunity to show attitudes, 
behavior, or actions not justified by religious law. Third, it triggers competition that does not support achievement, whether there is an element of intimacy between the two students sitting next to each other or vice versa.

Islamic Religious Education learning material in high school integrates Fiqh (sharia), Aqidah Ahlak, Al-Quran Hadith, and Islamic Cultural History. In Fiqh (sharia) learning, the response to gender is implemented in accordance with established legal normative principles. There is different treatment for male and female students due to the existing basic rules of sharia law. For example, the different procedures for covering one's genitals in performing prayers as well as the procedures for bowing and prostrating. Furthermore, women are not allowed to become prayer priests if the worshipers are male. The reason is not caused by the presence of different biological characteristics and structures of men and women; this is only the result of interpretation (as revealed by an informant). If it is applied equally between men and women, it will cause mental discomfort in prayer. Even though prayer is required to be khusyu'. There are differences, but that does not mean treating discrimination but paying more attention to the 'essence' of differences.

Another finding is related to the material related to the law of inheritance. Men get twice as much share as women. In this context, one of the Islamic Religious Education teacher) explained that, when the inheritance law stipulated in one of the verses of the Quran when it was revealed, the position of men at that time had a more outstanding obligation than women. It was mutually agreed upon between family members whom both received inheritance rights to get the same share. Based on reason, the responsibility of men and women in their respective families has the same significant burden. Based on mutual agreement, such legal provisions can be implemented, considering that it does not stimulate problems in the future.

\section{Competencies and Learning Materials}

Core Competencies and Basic Competencies of the Islamic Religious Education curriculum from a gender perspective appear neutral since there is no distinction or discrimination against certain genders. In addition, the syllabus, as well as its lesson plan, does not reflect gender bias. There has been no effort from Islamic Religious Education teachers to integrate gender issues in the learning process, especially in preparing the syllabus and lesson plans for Islamic Religious Education learning. According to the Minister of National Education Regulation Number 84 of 2008 essentially mandates that gender mainstreaming must be carried out through the learning process.

Several reasons cause the absence of efforts for incorporating gender issues into the learning process. The first reason is that the lack of attention of Islamic 
Religious Education teachers. It can be seen from the statement of a teacher who questioned the importance of gender issues. The second reason is that regulation of the Minister of National Education Number 84 of 2008 concerning guidelines for implementing Gender Mainstreaming in the educational sector has not been well socialized.

Observation for teaching materials of Islamic Religious Education contains gender-biased information. For example, the mention of the names of prophet companion and Hadith narrators is dominated by males. Meanwhile, the female Companions of the Prophet and Hadith narrators were less presented. Referring to the history of Islam, there have been numerous female companions of the Prophet Muhammad, who played a significant role in fighting for Islam, both as businessmen, nurses, as well as soldiers who were persistent in defending religion with their assets and lives and more than a hundred female Hadith narrators. The other case is that the depiction of male leadership in politics. The descriptions of kings, princes, sultans, or presidents presented in these books are related to masculine leadership nuances. Meanwhile, women's participation in politics is not almost portrayed.

Meanwhile, in the domestic realm, PAI books also show gender bias. Almost all PAI books place men as leaders in the family and women as subordinates in the family environment. Based on a textual understanding of the Surah An-Nisa verse (34), men are leaders for women. Because of this, the strict separation of the roles of men and women in the household colors the discussion in PAI books.

As exemplified in a textbook, it is explained that among the husband's obligations are to be a leader as well as provide a living in the family. While the wife should provide for the living provided by her husband, respect her husband and takes care of and educate her children. The duties of a wife are obeying her husband based on Islamic teachings. She has to maintain herself and her husband's honor and property; assist the husband in leading the welfare and safety of his family.

Gender disparities also appear in the pre-requisite of marriage. For example, it is stated that one of the conditions for marriage for a prospective husband is not being forced. At the same time, such conditions are not a requirement for wives. ${ }^{18}$ However, women are sometimes required to get married because of prepared marriage. It shows that gender differences have created injustice against women. The duties and responsibilities of a wife are highly diverse from that of a husband. The domination of men in the family often causes women

${ }^{18}$ Syamsuri, 'Poligami Ramah Perempuan; Catatan Kritis Atas Poligami KuantitatifKualitatif Perspektif Muhammad Syahrûr', Intinbath: Jurnal Hukum Islam IAIN Mataram 16, no. 1 (2017): 148-67. 
to be seen as second-class people who are obliged to serve their husbands totally without considering their own needs. It is in line with Muthali'in's research, which states that the myths of patriarchal culture hegemony and declaration of women as konco wingking, namely placing women as subordinate to men in unequal. ${ }^{19}$

\section{Learning Methods and Outcomes}

In classroom learning activities, Islamic education teachers apply a variety of learning methods. The application of this learning method can arouse students' motivation in learning. The learning methods often used are lecture methods, question and answer, dialogue, habituation, and exemplary.

They applied the eclectic learning method. It combines some methods proportionally, for example, explaining the meaning of the verses of the Quran related to the sincerity of worship, work ethic, or the development of science and technology. For subject matter related to daily behavior, teachers applied question and answer methods or sometimes asking students to present the subject matter. Moreover, the teacher often enriches and develops curriculum materials to increase students' knowledge of religious knowledge. To be contextual and relevant in daily life, the teacher relates it to existing social realities and provides experiences or examples. From a gender perspective, the various learning methods applied by teachers show the same treatment between men and women. Teachers provide equal opportunities to students and students in the learning process.

One of the characteristics of the 2013 curriculum is the implementation of a scientific approach. The teacher provides opportunities for students to develop understanding by using various learning methods by providing the broadest possible opportunity to encourage students to ask questions using the question word "why" or "how" related to the request for clarity of the material received. Students are also given extensive opportunities to observe as well as analyze reason logically and systematically. The teachers also provided the opportunity to communicate material through discussions.

PAI teachers carry out the PAI learning process based on the 2013 curriculum and integrated without biased gender. All are given the same opportunities to encourage students to improve learning outcomes, taking the advantages and disadvantages of learning strategies. Further, the teacher makes some improvements by implementing and evaluating students' learning achievement levels using the facilities and learning resources. To achieve learning outcomes optimally, teachers involve students in active participation through good

\footnotetext{
${ }^{19}$ Ahmad Muthali'in, Bias Gender Dalam Pendidikan (Surakarta: Muhammadiyah University Press, 2001).
} 
interactions between teachers, students, and learning resources. The teacher responds positively to the participation of students and shows conducive interpersonal relationships and enthusiasm in the learning process.

In assessing learning outcomes, the teacher emphasizes the proportionate assessment of attitudes, knowledge, and skills. It reveals that religious learning and character become the initial foundation for developing students' character in daily interactions. That is why PAI teachers get attention, especially working together with other teachers and all school elements. It is to help monitor the attitudes and behavior of students both inside and outside the school environment. Thus it can be obtained complete information data for all students, making it easier to formulate solution steps when there is a problem.

Based on observations of student learning outcomes related to variations in learning strategies imposed by Islamic Education teachers, it shows different learning outcomes. Students who are given the freedom to act but still pay attention to religious rules and values show that the learning outcomes have their characteristics. Even though they feel freedom, changes in thinking, attitude, and action determine their final attitude. They pay attention to religious norms even though they do not ignore aspects of rationality. Likewise, understanding gender issues are more related to religious rules and norms understanding differences.

Students who are given the freedom to determine learning strategies but pay attention to the agreement of classmates' agreement have slightly different learning outcomes. In acting, they use consideration of norms but must be able to show reasons for their rationality. It is different with learners who get freedom in the following learning. They, in setting actions, show more consideration of individual ratios. A comparison of Islamic Education learning characteristics from a gender equality perspective can be seen in the following table.

Table 1. Islamic Religious Learning-Based-Gender Equality

\begin{tabular}{|c|c|c|c|}
\hline $\begin{array}{l}\text { Learning } \\
\text { Strategies }\end{array}$ & Characteristics & Outcomes & $\begin{array}{c}\text { Understanding } \\
\text { Gender }\end{array}$ \\
\hline $\begin{array}{l}\text { Focused on } \\
\text { Free }\end{array}$ & $\begin{array}{l}\text { Students are given the } \\
\text { freedom to determine } \\
\text { learning strategies by } \\
\text { considering religious } \\
\text { values }\end{array}$ & $\begin{array}{l}\text { Changes in learning } \\
\text { outcomes in thinking, } \\
\text { behaving, and acting based on } \\
\text { religious normative-rational } \\
\text { considerations }\end{array}$ & $\begin{array}{l}\text { Having normative- } \\
\text { religious } \\
\text { understanding }\end{array}$ \\
\hline $\begin{array}{l}\text { Focused on } \\
\text { Free with } \\
\text { Agreement }\end{array}$ & $\begin{array}{l}\text { Students are given the } \\
\text { freedom to determine } \\
\text { learning strategies } \\
\text { based on class } \\
\text { agreement }\end{array}$ & $\begin{array}{l}\text { Changes in learning outcomes } \\
\text { in thinking, behaving, and } \\
\text { acting sometimes there } \\
\text { are normative-rational } \\
\text { considerations }\end{array}$ & $\begin{array}{l}\text { Have a normative- } \\
\text { rational } \\
\text { understanding }\end{array}$ \\
\hline
\end{tabular}


Free

Students are given the Changes in learning outcomes freedom to determine learning strategies in thinking, behave and

Have a rational based on taste and act based on individual desire considerations

Those three learning models based on gender equality as described can be read when the teacher describes the distribution of inheritance privileges. The first model accepts that women receive half of the portion of men due to the source of the verse of the Quran. And when the verse was revealed, most women had no role except to stay at home looking after their children and accompanying their husbands.

The second group looked more at the reasons that could develop under the existing circumstances. Even though women received half of the share of men at that time, if the condition of women has an equal role with men, the distribution of inheritance rights may be given equally based on a family agreement. Meanwhile, the third group sees the consideration of justice and equality for men and women who have the same degree in the family, so the distribution of inheritance rights is given the same, and no discrimination is imposed. Unless particular matters are emergency-incidental, the family can discuss them separately based on the consideration for helping other family members.

\section{CONCLUSION}

The implementation of Islamic Religious Education learning based-gender equality at senior high schools is as follows. First, Islamic Religious Education Learning does not precisely reflect gender bias since there is no distinction between men and women in taking lessons. The enlightenment of the differences in Islamic Religious learning materials is based on the essence of the source of Islamic law - al-Quran Hadith. It is related to the causes of legal provisions regarding the revelation of verses and Hadith. Second, several Islamic Religious Education learning models, namely, free-directed learning strategies with changes in learning outcomes in thinking, behaving and acting according to normativerational and religious considerations. Free learning with class agreement produces changes in learning in thinking, behaving, and acting. Sometimes there are normative-rational considerations. The next model of free learning, resulting in changes in learning in thinking, behaving, and acting, tends to follow individual ratio considerations. Third, the learning model impacts the students' understanding of gender equality. The first model created normative-religious understanding. The second learning model leads learners to have a normativerational understanding of gender. Then, the third learning model leads students 
to have an understanding of gender problems rationally. Finally, it is suggested to Islamic Religious Education teachers and all parties related to policymaking to develop Islamic Religious Education learning activities at schools. It concerns with these findings to formulate better learning activities and achieve higher quality learning outcomes. 


\section{REFERENCES}

Bungin, Burhan. Penelitian Kualitatif: Komunikasi, Ekonomi, Kebijakan Publik, Dan Ilmu Sosial Lainnya. Vol. 2. Jakarta: Kencana, 2007.

Ch, Mufidah, and Zainal Habib. Psikologi Keluarga Islam Berwawasan Gender. Malang: UIN-Malang Press, 2008.

Faiqoh, Iin Saroh. 'Bias Gender Dalam Kurikulum Mata Pelajaran Fikih Di Madrasah Aliyah Negeri Klaten'. Thesis, Program Pascasarjana UIN Sunan Kalijaga, 2009.

Hanafi, Nurachman, Iwan Jazadi, Nuriadi Nuriadi, Udin Udin, and Eni Djuhaeni. 'Students' Ability in Varying English Sentences: A Gender Approach'. Cendekia: Jurnal Kependidikan Dan Kemasyarakatan 17, no. 1 (2019): 1-16.

Hayat, Bahrul. 'Perempuan Dan Pendidikan Dalam Perspektif HAM'. Millah: Jurnal Studi Agama 11, no. 1 (2012): 193-217.

Hidayat, Rakhmat. 'Bias Gender Dalam Prestasi Akademik Siswa: Studi Tentang Perbandingan Prestasi Akademik Siswa Laki-Laki Dan Perempuan Di SMA 12 Bekasi'. Jurnal Pendidikan Dan Kebudayaan 17, no. 4 (2011): 472-79.

Kebudayaan, Kementerian Pendidikan Dan. 'Peraturan Menteri Pendidikan Dan Kebudayaan Republik Indonesia Nomor 84 Tahun 2014'. Jakarta: KEMENDIKBUD, 2015.

Maarif, Muhammad Anas, and Muhammad Husnur Rofiq. 'Pola Pengembangan Kurikulum Pendidikan Pesantren Berkarakter: Studi Pondok Pesantren Nurul Ummah Mojokerto'. TADRIS: Jurnal Pendidikan Islam 13, no. 1 (2018): 1-16.

Miles, Matthew B., and A. Michael Huberman. Qualitative Data Analysis: An Expanded Sourcebook. California: Sage Publications, 1994.

Moleong, Lexy J. Metodologi Penelitian Kualitatif. Bandung: PT Remaja Rosdakarya, 2002.

Muthali' in, Ahmad. Bias Gender Dalam Pendidikan. Surakarta: Muhammadiyah University Press, 2001. 
Ozaki, Reiko, and Melanie D Otis. 'Gender Equality, Patriarchal Cultural Norms, and Perpetration of Intimate Partner Violence: Comparison of Male University Students in Asian and European Cultural Contexts'. Violence against Women 23, no. 9 (2017): 1076-99.

Purnomo, Agus. 'Teori Peran Laki-Laki Dan Perempuan'. Egalita 1, no. 2 (2006).

Rusydi, Muhammad. 'Esoterisme Pemikiran Gender Nasaruddin Umar'. ANNISA: Jurnal Studi Gender Dan Anak 12, no. 2 (2020): 710-16.

Sofiani, Triana. 'Tafsir Agama Dan Kekerasan Berbasis Gender'. Jurnal Penelitian 5, no. 2 (2013).

Syamsuri. 'Poligami Ramah Perempuan; Catatan Kritis Atas Poligami KuantitatifKualitatif Perspektif Muhammad Syahrûr'. Intinbath: Jurnal Hukum Islam IAIN Mataram 16, no. 1 (2017): 148-67.

Syaodih Sukmadinata, Nana. Metode Penelitian Pendidikan. Bandung: PT Remaja Rosdakarya, 2008.

Umar, Nasaruddin. Argumen Kesetaraan Jender; Perspektif Al-Qur'an. Jakarta: Paramadina, 1999.

Unterhalter, Elaine. '2 Global Values and Gender Equality in Education'. Gender Education and Equality in a Global Context, 2007, 19. 